\title{
Nonstate governance of solar geoengineering research
}

\author{
Jesse L. Reynolds ${ }^{1,2}$ (D) Edward A. Parson ${ }^{1}$
}

Received: 1 July 2019 / Accepted: 19 March 2020 / Published online: 16 April 2020

(C) The Author(s) 2020

\begin{abstract}
As climate change's risks have grown and limits to primary responses become evident, solar geoengineering (or solar radiation modification) has risen in prominence as a potential complementary response. Widespread calls for expanded research have raised objections, based on anticipated links to potential future deployment and potentially harmful interactions with other climate responses. The unique concerns raised by solar geoengineering may warrant governing associated research with more care or scrutiny than other areas, but states have not engaged the issue. Given this, we analyze the potential for nonstate actors to provide governance functions needed to enable, control, and legitimate near-term, small-scale solar geoengineering research. Drawing on the theory of regulatory processes and nonstate actors as well as evidence from other issue areas, we describe six types of nonstate actors in terms of their capacity, knowledge, and interests relevant to governing solar geoengineering research: researchers themselves, the universities or other institutions that employ them, funders, academic publishers, professional societies, and advocacy nongovernmental organizations. We conclude that suitably configured collaborations among these actors can meet the additional governance needs of near-term solar geoengineering research. We consider potential limitations to nonstate governance related to legitimacy, effectiveness, and capture, and conclude that these are not severe under present conditions, but could become stronger if research grows toward deployment. Nonstate governance may even be preferable to state regulation of smallscale scientific activities, offering more flexible early exploration of options with the possibility of later transition into more state-led and legalized governance arrangements.
\end{abstract}

Keywords Climate change $\cdot$ Geoengineering $\cdot$ Solar radiation management $\cdot$ Research · Governance $\cdot$ Nonstate actors

This work was made possible through the support of the Open Philanthropy Project.

Jesse L. Reynolds

j.1.reynolds@uu.nl

1 School of Law, University of California, Los Angeles, 385 Charles E. Young Drive East, Los Angeles, CA 90095, USA

2 Utrecht Centre for Water, Oceans and Sustainability Law, Utrecht University, Newtonlaan 201, 3584 BH Utrecht, The Netherlands 


\section{Introduction}

As the gravity of climate change risks and the insufficiency of likely responses become clearer, solar geoengineering (also called solar radiation management or modification) has increased in prominence and controversy. Although evidence suggests that it could reduce climate change risks, its techniques remain underdeveloped and their efficacy and risks poorly characterized. Many observers have called for expanded research, including small field experiments. Even those that would pose negligible environmental risk have raised controversy and opposition, however, principally due to social, political, and governance challenges raised by potential future operational use (Reynolds 2019). The result has been extended debate over how to govern research, while enquiry suffers from continued delay and resource scarcity. If solar geoengineering research raises risks and challenges distinct from other fields, then targeted governance may be warranted, yet states have thus far been reluctant to act or even participate in the debate. Given limited state involvement, governance by nonstate actors may offer a promising route to manage the tension between calls for research and significant concern and opposition.

We explore whether and how nonstate actors could govern the challenges posed by solar geoengineering research. Drawing on the theory of regulatory processes and nonstate actors, evidence from other issue areas, and the characteristics of relevant nonstate actor types, we conclude that nonstate actors could effectively and legitimately govern solar geoengineering research. Additionally, even if state-led governance were available, nonstate governance may have significant advantages in this area.

Our analysis has two limits. First, we consider only near-term governance of solar geoengineering research that is ongoing or likely to be proposed within a decade or so. This includes indoor work (modeling and lab studies), passive observations, and outdoor experiments small enough to have negligible environmental impacts and no transboundary risks. Larger-scale perturbations, whether for research or operational purposes, would present more severe but less immediate challenges that would presumably require state leadership. Second, we consider mainly the structure of governance, participating actors, and their potential roles, not the specific content of the rules and norms. Indeed, developing and adapting these would be an early task of any governance system.

\section{Solar geoengineering: promise, concerns, and governance needs}

Solar geoengineering would intentionally alter the Earth's energy balance without directly changing atmospheric greenhouse gas concentrations, typically by reflecting or scattering a small amount of incoming sunlight (National Research Councils 2015). The most widely discussed technique would mimic volcanic eruptions' natural cooling effect by spraying lightscattering aerosols in the stratosphere. Of this approach, the Intergovernmental Panel on Climate Change (IPCC) concluded "with high agreement that it could limit warming to below $1.5^{\circ}$ C" (IPCC 2018), an ambitious target that appears extremely difficult to achieve otherwise. Solar geoengineering could complement_not replace_-mitigation (i.e., emissions cuts), adaptation, and $\mathrm{CO}_{2}$ removal, reducing risks in ways that these responses alone cannot.

Solar geoengineering also presents significant environmental risks and social challenges. Its reversal of greenhouse-driven climate change is spatially and temporally imperfect. It would counteract precipitation changes more strongly than temperature ones (National Research 
Councils 2015, pp. 52-59). Some environmental risks are strongly linked with social and political processes. For example, if an extreme program of solar geoengineering was used to mask several degrees of heating, then any sudden and sustained cessation would rapidly unmask it, with severe impacts (National Research Councils 2015, pp. 59-66). Other risks are predominantly political. Overreliance on solar geoengineering could undermine needed efforts on mitigation or other responses (Hale 2012). Future deployment without competent, prudent, and legitimate international control could trigger international destabilization or conflict (Schellnhuber 2011).

In view of the tension between solar geoengineering's potential contributions and risks, multiple bodies have called for expanded research, including scientific organizations (e.g., American Geophysical Union Council (2009); American Meteorological Society Council (2013)), assessment bodies (e.g., Shepherd et al. (2009); National Research Councils (2015)), and scientifically sophisticated environmental organizations (Environmental Defense Fund 2015; Natural Resources Defense Council 2015; Union of Concerned Scientists 2019). Yet some concerns about potential future deployment have also been directed at scientific activities, even with negligible direct environmental risks. For example, solar geoengineering research might unduly undermine mitigation or other responses (National Research Councils 2015, p. 10). Some critics suggest that research might create political or economic dynamics that tend to sustain and expand the endeavor, independent of expected net benefits or democratic preferences__ a form of sociotechnical lock-in (Shepherd et al. 2009, p. 39). Some opponents are so certain that deployment could never be appropriate under any conditions that they argue research has no value (e.g., Hulme (2014)).

These concerns have been forcefully raised to oppose research. In effect, these debates treat it as a proxy for future implementation, rather than a low-risk way to reduce uncertainties and inform future decisions (Parker 2014). The controversy has hindered research and attempts at prioritization and strategic planning. Financial support is neither large, state-driven (Necheles et al. 2018), dedicated, nor mission-oriented.

Outdoor experiments face particularly strong opposition, even though these concerns could equally apply to other forms of research, including computer modeling, which are proceeding with limited resources but little overt opposition. Only two outdoor experiments related to solar geoengineering have been conducted thus far, one of limited value (Izrael et al. 2009) and another that was only characterized ex post as informing solar geoengineering (Russell et al. 2013). Within the UK's Stratospheric Particle Injection for Climate Engineering (SPICE n.d.) project, a proof-of-design test of a tethered balloon delivery system was canceled following protests by activist nongovernmental organizations (NGOs) and disclosures of intellectual property irregularities (Stilgoe et al. 2013). A few other outdoor experiments are proposed or planned. The Stratospheric Controlled Perturbation Experiment (SCoPEx), in development by Harvard scientists since 2012, would inject a few kilograms of aerosols in the stratosphere from a balloon to study particle size distribution and chemical effects (Dykema et al. 2014). A group from the University of Washington and Stanford University is considering a marine cloud brightening experiment (Wood and Ackerman 2013). The state of Queensland is supporting development of operational but regional-scale projects aiming to protect the Great Barrier Reef (McDonald et al. 2019). Some outdoor experiments in surface albedo enhancement have also been conducted (Field et al. 2018).

These controversies have generated extensive debate. But many governance needs are not unique to solar geoengineering but common to many areas: e.g., providing and prioritizing resources; evaluating scientific merit; assessing and controlling direct environment, health, and 
safety risks; ensuring integrity; and promoting open dissemination of research aims, methods, and results. These are routinely provided by existing regulations, program management, and self-regulatory procedures such as peer review (Burger and Gundlach 2018). Insofar as needs are common to many research areas, we do not emphasize them here.

Rather, our main concern is with the additional governance needs specific to solar geoengineering research. Many of these follow from the field's heightened concern and controversy, which in turn derives from perceived linkages between research and potential future deployment. Even for familiar needs including assuring scientific quality and managing direct risks, heightened public concern and controversy may warrant greater scrutiny or control, or more open and deliberative processes, than in other areas. Solar geoengineering may also require issue-specific planning and coordination because the research serves a mission of informing future climate response capabilities, rather than purely advancing knowledge (MacMartin and Kravitz 2019). Finally, concerns about indirect social or political effects such as potential lock-in or undermining mitigation must also be addressed, even if these operate at a larger scale than individual projects.

Although states are usually the leading actors in planning and funding research and controlling environmental risks, they have had limited involvement in solar geoengineering debates. Publicly funded programs are few, small, and generally oriented toward identifying risks (Schäfer et al. 2015; Necheles et al. 2018). States have shown little interest in expanding research support, developing focused governance, or-with small exceptions-supporting outdoor experiments, despite a decade of recommendations to do so (Shepherd et al. 2009). Given the issue's controversy, risk-averse leaders may see more loss than gain in raising solar geoengineering's profile, a situation that appears unlikely to change soon. In the absence of effective state leadership, nonstate actors may be able to provide the governance necessary for near-term research to proceed.

\section{Nonstate governance: solar geoengineering and elsewhere}

We use "governance" to denote sustained, goal-oriented use of authority to influence behavior (see Black (2001)). Scholars have identified many types of nonstate governance, diverse in participating actors, forms, and methods. Participating actors can include businesses, other private actors and NGOs, and intergovernmental organizations, with various potential interactions among these, particularly overlap between governing actors and targets. Although the concept of nonstate governance presumes that nonstate actors dominate its development, implementation, and enforcement, mixed forms are also possible in which states complement the roles of nonstate actors (Gunningham and Grabosky 1998). Modes of state involvement can be formally recognizing nonstate actors' authority, overseeing them, or delegating authority to them (e.g., Garcia Martinez et al. (2007)). Even when states are formally absent, nonstate governance operates in the shadow of potential state intervention. Scholars have also examined transnational private regulation, by which nonstate governance exercises influence across borders (Heyvaert 2018). Nonstate governance can vary in its degree of legalizationmeaning its obligation, delegation, and precision (Abbott et al. 2000) - ranging from informal reputational networks to enforceable contractual obligations (Black 2001). Nonstate governance can use many of the same tools as state regulation, such as rules, statements of principles, codes of conduct, social norms, market incentives, information sharing and disclosure, provision of resources, and certification or other forms of recognition. Over time, 
nonstate governance can gradually legalize and evolve toward increased roles for state actors. Nonstate governance has been particularly investigated in the environmental context (Bernstein 2011; Heyvaert 2018).

Targets may be motivated to comply with nonstate governance for several reasons (Winter and May 2001). They may have internal normative commitments that the governance affirms, amplifies, and coordinates. Targets may respond to social norms and reputational effects channeled through collective judgments of approval or disapproval. And they may have various material incentives, including gaining funding, recognition, or access to information or other resources. These incentives can have the structure of coordination or collective action problems, which nonstate governance can help to overcome.

A few examples illustrate the diversity, across multiple issue areas, of forms of nonstate governance, participating actors, and mechanisms of influence.

- Professional societies such as medical and bar associations exercise state-delegated authority to control professional licensing and conduct.

- Human subject research is governed internationally through guidelines issued by a confederation of professional societies (World Medical Association 2018) and enforced indirectly in the USA as conditions of federal funding.

- In response to early concerns about recombinant DNA research, scientists collectively developed biosafety principles, later adopted by the US National Institutes of Health (Lentzos 2017).

- Due to polarized US abortion politics, many aspects of assisted reproductive technologies are not regulated at the federal or state level, but by certification and accreditation through the American Society for Reproductive Medicine and other professional organizations.

- After the 9/11 terrorist attacks, a large group of scientists, funders, and scientific journal editors issued a joint policy on publishing biomedical research that might be vulnerable to terrorist or other misuse (Journal Editors and Authors' Group 2003).

- After the 1979 Three Mile Island accident, US nuclear power operators formed an industry association to promulgate safety and reliability standards, recognizing that accidents at any plant put them all at risk of strict regulation or nationalization (Rees 1994; see also Reynolds (2014)).

Nonstate governance has both advantages and disadvantages relative to the state-led counterpart (Coglianese and Mendelson 2010). It can respond more nimbly to dynamic conditions and emerging knowledge because nonstate actors are less subject to slow-tochange legal or administrative constraints. Nonstate actors may have stronger incentives to govern efficiently, due to competition from state or other nonstate regulators. They may be more able to take action on controversial matters where states are administratively, politically, or legally constrained. Internationally, nonstate governance benefits from flexible participation, allowing negotiations to include just those actors needed for effective action, rather than all members of the convening intergovernmental organization with associated risks of holdouts or gridlock (Bodansky 2013, p. 547). Collective self-regulation may offer particular benefits, among which are superior access to information and building mutual familiarity and trust. With these advantages, nonstate governance often develops in contested cross-border issues including controlling labor and environmental impacts of global supply chains (Bartley 2011) and in dynamic, technically complex areas such as emerging technologies (Marchant and Wallach 2015). 
Nonstate governance also has disadvantages. Self-regulation arrangements may lack incentives to develop and enforce strong rules, particularly for external effects borne by outside parties. Nonstate governance may be subject to capture, by which some targets unduly influence governance arrangements - although it is unclear whether this risk is more severe in state or nonstate settings. Nonstate governance may lack legal requirements for transparency and public participation and may thus be viewed as less accountable or legitimate than state regulation. Its weaker legalization may also limit enforcement, since nonstate systems usually cannot deploy strong actions - e.g., injunctions, fines, or imprisonment. Finally, sometimes multiple nonstate actors have promoted distinct, inconsistent governance approaches. While this pluralism can promote experimentation and creativity, it can also increase compliance costs, reduce effectiveness, and spread confusion.

In debates thus far on solar geoengineering, nonstate actors have advanced several governance proposals and participated in governance in limited ways. Multiple statements of highlevel principles have been proposed (Jamieson 1996; Morrow et al. 2009; Asilomar Scientific Organizing Committee 2010; Bipartisan Policy Center's Task Force on Climate Remediation Research 2011; Solar Radiation Management Governance Initiative 2011; Chhetri et al. 2018; Gardiner and Fragnière 2018). One of these, the Oxford Principles, was subsequently endorsed, with qualifications, by a parliamentary committee and the UK government (Great Britain Department of Energy and Climate Change 2010; UK House of Commons Science and Technology Committee 2010; Rayner et al. 2013). Three NGOs are working to advance governance dialogs and raise awareness of the issue among national governments and intergovernmental organizations: the Carnegie Climate Governance Initiative, the Forum for Climate Engineering Assessment, and the Solar Radiation Management Governance Initiative. For solar geoengineering research, several professional bodies and environmental groups have issued statements supporting research (American Geophysical Union Council 2009; Institution of Mechanical Engineers 2009; Shepherd et al. 2009; American Meteorological Society Council 2013; International Commission on Clouds and Precipitation 2014; Environmental Defense Fund 2015; Natural Resources Defense Council 2015; Union of Concerned Scientists 2019), and one legal scholar has drafted a detailed proposal for a code of conduct based on existing international law (Hubert 2017).

Two of the solar geoengineering research projects discussed above, one past and one planned, illustrate concretely the potential influence of nonstate governance. The SPICE project received funding in 2009 from the UK Research Councils, including for a small outdoor equipment test. Among the Councils' reviewers was one author of the Oxford Principles, who suggested applying the Principles by subjecting the outdoor test to a "stage gate," which would require certain criteria to be met before proceeding (Kruger 2018). SPICE leadership agreed to observe the principles and committed not to patent or profit from the results (SPICE n.d.; Engineering and Physical Sciences Research Council 2012). The outside test was canceled following the stage gate, due to unsatisfactory stakeholder engagement and the disclosure that some participants had applied for a patent, contrary to project leaders' commitment to the Oxford Principles. Planners of the SCoPEx experiment, in addition to complying with all relevant regulations, are attempting to develop and implement a viable model of nonstate governance. In fact, in addition to their scientific aims, they have articulated an additional top-level objective to proceed "in a manner that exemplifies good governance, developing and implementing norms, mechanisms and practices that can serve as useful templates for possible future solar geoengineering field experiments" (Keutsch Research Group, Harvard University n.d.). To this end, the group has delayed their proposed experiment 
several years, foresworn patent claims (Keith and Dykema 2018), supported an exercise to elicit public input (Consortium for Science, Policy, and Outcomes n.d.), and established an independent Advisory Committee.

Despite these early efforts to apply nonstate governance to solar geoengineering research, and the large literatures on nonstate governance and on the governance of solar geoengineering, little scholarly work has examined the intersection of these: the potential to apply nonstate governance to solar geoengineering research. Several authors have stated that particular nonstate actors could or should contribute to governance, or suggested broad aspirations for how it could develop that imply nonstate involvement-e.g., by calling for "bottom-up norm creation" rather than formal regulation (Shepherd et al. 2009; Bodansky 2013; Armeni and Redgwell 2015; National Research Councils 2015; Sargoni 2016; Zelli et al. 2017; Brent 2018; Chhetri et al. 2018; Nicholson et al. 2018; Frumhoff and Stephens 2018). Prior scholarship, however, has not examined potential nonstate governance of solar geoengineering research with explicit consideration of specific needs, the implications of states' lack of engagement, or the potential roles and resources of particular types of nonstate actors in contributing to governance (although a partial exception is Parker (2014), pp. 11-13, who considers researchers' and funders' potential roles).

\section{Nonstate governance of solar geoengineering research: potential actors and their contributions}

To assess the feasibility of nonstate governance systems fulfilling the incremental governance needs associated with near-term solar geoengineering research, in this section we consider six specific types of nonstate actors routinely involved in research: the researchers themselves, the universities or other institutions that employ them, funders, academic publishers, professional societies, and advocacy NGOs, both environmental and other. For each type of actor, we assess their ability to contribute based on three characteristics:

1. Capacity: To what extent can they influence the focus, process, and impacts of research?

2. Knowledge: What knowledge do they possess to guide their exercise of this capacity in pursuit of effective governance?

3. Interests: How well do their motivating interests - both material and normative - align with the aims of effective governance?

\subsection{Researchers}

In addition to being targets of governance, researchers are also on the front lines as potential sources of governance. They choose what experiments, projects, risk management measures, and other procedures to undertake, individually and in consultation with their peers. There is a robust and long-standing tradition of scholarly self-regulation on matters ranging from broad defense of scientific integrity to specific concerns about novel risks and impacts from particular methods. Researchers also have detailed knowledge of present methods and techniques, their likely contributions and limits in addressing specific scientific questions, and their associated risks and potential responses to mitigate these. 
Researchers' interests, like those of other actors, reflect a combination of material selfinterest in professional success and advancement, social approval and reputation, and internal normative commitments to advancing knowledge and doing so in socially beneficial ways. These interests are all linked to other actors - including their employers, funders, scholarly publishers, and professional societies, as well as their collective community of peers - on whom they depend for institutional and financial support, communication outlets, recognition, and validation.

Solar geoengineering researchers are presently a small community within larger disciplinary groups and institutions. They acknowledge and are sensitive to the risk and controversy associated with their work, and recognize that they depend on their collective reputation because the public and decision-makers are unlikely to differentiate among them individually (Anshelm and Hansson 2014). They are thus motivated to avoid reckless or inflammatory statements and actions, and to police these in other researchers - as geoengineering researchers' widespread censure of a badly designed, over-hyped, and possibly illegal ocean fertilization experiment suggests (Marshall 2012). In some fields, scientists act as entrepreneurs promoting commercial applications of their work and thus face incentives that can be in tension with scientific norms, but this is not currently the case for solar geoengineering and appears unlikely. Present projections of the structure of any potential future geoengineering enterprise suggest that there will not be great fortunes to be made, and state actors will be in charge of making major decisions. Some researchers might seek patents and aim to profit from future public procurement contracts (Reynolds et al. 2017), but there are few signs of such activity at present. Indeed, the interests of the current cohort of scientists appear not to be grounded in promoting solar geoengineering's use, but in the increasing gravity of climate change risks and the limited prospects for mitigation to reduce them (e.g., Caldeira (2008); Shepherd et al. (2009); Parson and Keith (2013); National Research Councils (2015); MacMartin and Kravitz (2019)).

The most important constraints to solar geoengineering researchers' ability to contribute to effective governance pertain not to interests, but to capacity and knowledge. Scientists' capacity to self-regulate collectively is limited because they lack larger-scale resources to coordinate or to change behavior beyond what is feasible through voluntary agreements (see Parker (2014), pp. 11-12). Researchers also lack knowledge about their work's indirect, longer-term, or socially and politically mediated risks and challenges, and about effective governance approaches to address these (Marchant and Wallach 2015). These must come from other types of actors.

\subsection{Research institutions}

Most researchers, in solar geoengineering as in other fields, are employed by universities or other research institutions. As employers, these bodies have authority to hire or fire, promote or demote, and provide or deny resources, honors, or platforms. This represents substantial capacity to govern work conducted by their employees, students, and affiliates when it affects matters of public concern. The exercise of this authority is routine, embodied in mechanisms like the institutional review boards (IRBs), grant management, technology transfer, and compliance offices for environment, health, and safety, discrimination, and other areas of regulatory concern. These institutions also have large bodies of accumulated knowledge on research governance, including in rapidly evolving and controversial areas such as work with human embryos. They have strong interests in maintaining their good reputations, which affect 
their success in funding, recruitment, and other sources of support and legitimation. They are thus sensitive to reputational damage related to research and its oversight, balancing efforts to defend freedom of inquiry even in controversial areas with strict oversight, including dismissal, in cases of scientific misconduct (Levelt Committee et al. 2012). Because of their large scale and multidisciplinary reach, their pursuit of these aims is unlikely to be easily swayed, either by strong interests of one research group or by targeted objections of a few activists.

The main limitations of research institutions for governing solar geoengineering research are that they only have oversight authority over their own employees and associates, and that they may lack knowledge of risks and responses specific to solar geoengineering research. These deficits can both be mitigated. Knowledge and capacities developed in other scientific areas are likely to be transferable, at least partially, to solar geoengineering research. Universities are prominent and effective forums for information gathering and sharing activities and consultations on matters of public concern. They conduct such activities routinely, both in pursuit of their general mission to advance knowledge and to inform their own practices. And research institutions, like researchers, have open cultures, shared reputational interests, and informally recognized leaders. They are thus likely able to effectively consult and coordinate to collectively address challenges posed by controversial areas and consequently extend the reach of agreed norms and practices.

\subsection{Funders}

Most scientific research depends on external funding, of which a substantial fraction is private. The world's largest private research funder, the Bill \& Melinda Gates Foundation, gave 5 billion USD in grants in 2018, on the same order of magnitude as the US National Science Foundation's 6.6 billion USD budget (Science News Staff 2018; Bill and Melinda Gates Foundation n.d.-a). Solar geoengineering researchers rely disproportionately on nonstate sources (Necheles et al. 2018).

Funders have the capacity, knowledge, and interest to contribute to governance of research in areas they fund, directly for their own grantees and with varying degrees of indirect influence over other activities in the same area (see Parker (2014), pp. 12-13). Funders' exercise of their governance capacity regularly encompasses diverse types of conditions and requirements imposed on projects they fund, such as procedural standards, review criteria, operational requirements on subsequent research conduct and dissemination of results, and participation in ancillary processes. For example, the Gates Foundation has contractual terms regarding human research subjects, intellectual property, privacy, vicarious legal responsibility, and compliance with local laws and regulations, including those concerning ethics (Bill and Melinda Gates Foundation n.d.-b). Funders that are large presences in particular research fields - those that are large overall, as well as pass-through foundations and others focusing on specific issues-exercise significant strategic influence over norms and practices in those entire fields, through their own bargaining power with scientists and institutions and through consultation and coordination with other funders.

Effective grantmaking requires funders to have deep knowledge of the fields they support, which they develop and keep current by retaining expert program staff and through the detailed information they receive in funding applications and other interactions with researchers. They thus have good understanding of current priorities and approaches, attendant challenges and controversies, and potential responses. Funders who support multiple areas of 
high-stakes or controversial research are also well-positioned to generalize this learning across fields.

Like large research institutions, major funders have broad substantive scope; even funders targeting specific areas such as climate change or energy have much wider scope than solar geoengineering. Funders also, again like research institutions, are sensitive to potential reputational harm that could follow from supporting activities widely viewed as reckless or illegitimate. They thus have interests in constructively addressing social and political controversies related to their research agenda, and promoting and complying with widely accepted governance norms for responsible research.

\subsection{Publishers}

As the primary means of communicating scientific findings, academic publishers are important gatekeepers for research. Journals are numerous and hierarchically ranked according to prestige, reputation for quality, and visibility, with few at the top and many at the bottom. Publication in respected outlets is the main currency of academic research, valuable for scientists' careers, reputations, and ability to transmit their ideas.

Publishers can exercise significant governance authority over researchers through conditions or requirements attendant on publication. Indeed, a core mission of academic publishers is to impose standards of scientific quality control. Editors of journals and other outlets also routinely exercise their gatekeeping function to require conformity with relevant ethical norms, on diverse matters including protection of human research subjects, treatment of animals, intellectual property, confidentiality, security-sensitive information, and compliance with local laws and regulations. In coordinating these requirements and identifying related best practices, they are aided by professional bodies such as the Council of Science Editors in the USA and the Committee on Publication Ethics in the UK. Prominent examples of publishers exercising authority are Nature's requirement that certain types of human stem cell research submit ethics statements and in some cases submit to ethics review (Nature 2018), and the agreement among multiple leading journals on requirements for publication of dual-use biomedical research (Journal Editors and Authors' Group 2003; Editors 2012).

Individual editors must deal with large number of submissions and may have limited knowledge of controversies specific to a particular field. Most journals, however-especially those of higher status - have many editors with large informal networks of peer reviewers and advisors, and so are able to access information about concerns and to identify researchers with reputations for suspect practices or norm transgression. Like research institutions and funders, prominent publishers also have reputational interests in avoiding association with work viewed as reckless or violating widely agreed norms, and operate with a breadth of scope that limits their vulnerability to any individual scientist or research group.

The main limitations to publishers' effectiveness as governance participants are related to the large number of journals, which makes collective organization difficult and means that many journals, particularly lower-status ones, have limited ability to decline submissions - and indeed may have an interest in gaining attention by publishing controversial work. Coordination difficulties may be mitigated by the concentration of journal ownership among relatively few publishers (Larivière et al. 2015), but norm-violating scientists can still usually evade conditions by shopping for a lenient journal. Because the promulgation of research norms is led by top journals, this shopping comes at the cost of lower visibility and prestige. However, this disincentive may be weakened by current disruption of the traditional academic publishing 
model, visible in the proliferation of new, open access titles and the increasing prominence of online publication outlets. In fact, those researchers willing to break norms and court controversy may be precisely those least interested in highly ranked journals and most inclined to pursue wide public attention through means including low-status journals, nonscientific outlets, or social media.

\subsection{Professional societies}

Like many other professionals, researchers self-organize into discipline-based professional societies that enjoy significant stature and convening authority among relevant cohorts. These offer recognition and honor among communities of peers, as well as networking and communication opportunities. Such societies have some-but limited - capacity, knowledge, and interest to monitor and enforce members' compliance with research norms. They sometimes promulgate formal and informal standards, and can discipline or expel members for serious misconduct (American Association for the Advancement of Science 2018; National Academy of Sciences 2018). Although disciplinary actions are infrequent, they are an important means by which fields enforce norms to protect their shared reputations.

Scientific societies already police their members. The examples of nonstate governance, given above in section 3, include several in which professional societies such as the American and World Medical Associations, the US National Academies, and the UK Royal Society played important roles. Moreover, policies of publishers and funders are often developed in concert with guidelines issued by professional societies. For example, Nature's stem cell research policy draws on guidelines of the International Society for Stem Cell Research (Nature 2018). These societies also have, in their leaders and members, access to the specific expertise to assess proposed research's potential value, risks, associated controversies, and conformity with relevant norms. And like research institutions, funders, and publishers, they have collective reputational interests that are diffuse enough that a single rogue scientist is unlikely to have meaningful influence over the society.

Professional societies have already been active in debates on solar geoengineering research. The Royal Society and US National Academies released influential reports (Shepherd et al. 2009; National Research Councils 2015; see Gupta and Möller (2018)), and a committee of the latter is developing an agenda and recommended governance approaches. Others have issued statements calling for more research (American Geophysical Union Council 2009; Institution of Mechanical Engineers 2009; American Meteorological Society Council 2013).

Among limits to the potential governance role of professional societies are their substantive scope, their member-driven decision-making, and the rarity and narrow focus of their disciplinary actions. Their scope, usually either along disciplinary lines or encompassing all of science, suggests they may lack focused interest or expertise related to controversies in a particular field, especially one like solar geoengineering for which multiple disciplines are implicated. Societies' official statements on important social issues must be acceptable to most active members, which for controversial areas usually include both vigorous proponents and critics. Thus these statements - if made at all - tend to be generic and weak. And their disciplinary actions are highly limited. They traditionally address only clear violations of scientific integrity such as falsification or plagiarism, and are now expanding to include personal misconduct such as harassment and bullying. Application of these mechanisms to societal implications of contentious evolving research areas would be even more severely limited than policy statements. 


\subsection{Advocacy nongovernmental organizations}

Advocacy NGOs play strong, increasingly recognized roles, both in the political processes that lead to governance and in its subsequent development, monitoring, and enforcement (Boli and Thomas 1999). They perform these both informally, through mechanisms such as pressure campaigns or "naming and shaming" norm violators (Keck and Sikkink 2014), and formally, through such means as codified private regulation and quasi-official roles in some environmental, human rights, and other agreements (Edwards 2009). Advocacy NGOs are particularly active and effective on environmental issues (Betsill and Corell 2008), where some have developed reputations that grant them widely recognized authority among policy-makers, scientists, and concerned citizens. For example, NGOs have played leading roles in recent research, advocacy, and litigation aiming to hold fossil fuel interests to account for their contributions to climate change and their support for efforts to discredit associated scientific knowledge (Ekwurzel et al. 2017).

Thus far, environmental groups' engagement on solar geoengineering and research has been heterogeneous. Some groups reject future use under any conditions, and thus also reject research (Friends of the Earth 2015), while others support research subject to various conditions including effective governance (Environmental Defense Fund 2015; Natural Resources Defense Council 2015; Union of Concerned Scientists 2019). Representatives from these latter groups are currently participating on both the US National Academies and the SCoPEx advisory committees.

Environmental groups' likely roles in nonstate governance of solar geoengineering research are shaped and limited by this heterogeneity among them. Several leading groups have substantial expertise in current scientific debates, governance concerns, and the context of the broader climate change issue. They are thus potentially valuable participants in collaborative processes to develop, implement, and assess research governance arrangements. But the more familiar mechanisms of NGO influence - public and policy campaigns - are stronger when multiple groups, or at least the major ones, express consistent views. Present division among NGOs suggests that such consistency is only likely to be possible as a response to conspicuous instances of reckless or norm violation. NGOs other than environmental and scientific ones have not yet been involved in solar geoengineering debates, but as it and the climate change issue grow more prominent and contentious, religious, labor, civic, and development groups can bring larger constituencies and potentially increased legitimacy to the governance system.

\section{Assessment of nonstate governance}

\subsection{Required governance functions}

The previous section assessed the potential resources and roles of types of nonstate actors in governing solar geoengineering research. We do not specify the substantive content of governance rules and norms, because defining these - and the associated consultation, assessment, and adaptation - will be an essential and contested task for whatever system is adopted. Still, certain general contours are evident. Long and Parson (2019) characterize three basic functions of research governance as enabling, controlling, and legitimation. The debate over 
solar geoengineering research governance has elaborated these with somewhat greater, although not total, specificity.

Enabling research requires providing financial support and other necessary resources, coupled with processes to define strategic priorities and to assure high scientific quality. The heightened controversy over solar geoengineering research suggests that these assurances must be provided with greater care and scrutiny than in other areas. Such review and prioritization may also state provisional limits to what activities will be supported-expressed in scale, methods, or other aspects - to assuage concerns about thoughtless expansion of research or a "slippery slope" to deployment.

The control function concerns limiting potential risks and harms. We address here near-term proposals, whose direct impacts and risks are very small. As with quality assurance, however, heightened concern about solar geoengineering research calls for greater care and scrutiny, including requirements that pertain more to indirect, socially and politically mediated effects than direct risks. These former effects are serious concerns, but do not fit well with governance mechanisms for individual projects. Rather, they are more effectively addressed at the program level, through assessment and consultation procedures that are not exclusively scientific and whose scope encompasses the entire research enterprise, its context, and potential implications. These would operate separately from, and at a higher level of generality than risk assessment for individual projects, convened and supported by universities, funders, or other involved actors. Although individual projects would not have overall responsibility for these, their leaders would need to participate.

While legitimation of the enterprise is an additional requirement of effective research governance, it reflects a broad social and political attribution to an area and individual projects within it: that these are socially valued and being pursued responsibly. Effective legitimation is not normally pursued separately, but emerges from other processes as outlined above: transparent procedures of defining priorities and evaluating scientific quality, assessment of risks, public engagement on potential impacts and societal significance, and more.

\subsection{Outline of a nonstate governance system}

The first basic governance function, enabling high-quality research, is routinely and effectively done by nonstate actors in many areas, with specific roles filled by funders, publishers, and others. Funding for solar geoengineering research has been scant, but if nonstate funding expands substantially, funders can raise the saliency and credibility of the enterprise through coordinated and transparent review. An accessible clearinghouse of activities proposed and undertaken, results, data, and publications would also advance these aims. Defining strategic research priorities would also benefit from coordination. Although this function, like research funding, is usually led by states, it is not beyond the reach of nonstate actors if multiple funders, scientific communities, and institutions collaborate. Because defining priorities for solar geoengineering research is likely to implicate the complete climate response and multiple linked societal values, broadening this consultation even further, to include scientific societies, environmental groups, and other civil society actors, would be beneficial.

The second general governance function, controlling potential harms and risks from research, unavoidably involves imposing requirements and burdens on scientists. It would be a mark of effective governance that these requirements are well aligned with widely accepted norms. These would have to be defined collaboratively, and adapted in response to advancing knowledge and experience. In view of the resources and authority they deploy, 
funders and research institutions would play a leading role in defining and implementing norms and procedures. These should be broadly consistent with researchers' normative commitments and shared reputational interests - at least to the degree that most of them perceive the legitimation and access to resources that the governance provides to be worth the associated burden. Mutual monitoring and enforcement of norms by researchers will then augment the material incentives deployed by funders and institutions. This collection of incentives and enforcement mechanisms can be complemented as necessary by the participation and support of publishers, professional societies, and NGOs. The complete governance system would be substantially stronger than mere self-regulation by researchers. Rather, it would coordinate participation by multiple layers of actors deploying different combinations of resources, making aggregate incentives strong enough to secure widespread compliance.

Assessment and consultation regarding indirect, socially and politically mediated challenges and wider societal impacts - concerns such as mitigation displacement, socio-technical lock-in, governance needs for future challenges or decisions related to deployment, and risks of international destabilization or conflict-would require mechanisms distinct from those that define and enforce rules for individual research projects and programs. Several major types of nonstate actors - such as leading universities, funders, and scientific societies - could jointly undertake exploration and consultation on these issues. All actor types identified here should be involved, as well as wider collections of diverse publics, NGOs, and decision-makers, preferably in multiple, parallel processes to expand reach. These could address general issues regarding solar geoengineering research, its implications, and linkages to other climate responses without unduly burdening individual projects. Output from these processes would be integrated into periodic assessment and review of the research program, conducted both from a scientific and a broader societal perspective, to reconsider the strategic priorities and governance requirements of the program, including its continuance.

\subsection{Limitations}

Nonstate governance of solar geoengineering research will be subject to several objections and limitations. First, some observers may judge it necessarily illegitimate by virtue of state actors not participating, at least not initially. This criticism is axiomatically valid if states (presumably democratic ones) are regarded as the only sources of legitimacy. But scholars have recognized other potential bases for legitimacy: effectiveness, efficiency, expertise, and open, fair procedures (Bernstein 2011; Baldwin et al. 2012). While our analysis cannot surmount such an axiomatic critique, nonstate governance can and should strive to achieve these other bases for legitimacy and to remain accountable to a broad and diverse collection of constituencies.

Second, because nonstate governance commands weaker authority than state regulation, it may not be effective in preventing all violations. For example, it would be weaker if researchers have access to resources outside participating funders, if rogue scientists are unaffiliated with any of the identified actor types, or if there is serious normative divergence among these groups. Conversely, nonstate governance may be unable to mobilize sufficient focus to police marginal violations, with the risk that these minor but overlooked transgressions gradually would become more numerous or severe.

Third, some critics may suggest that nonstate governance is more vulnerable than state alternatives to capture, in which governance targets come to control terms of governance for their own benefit at the expense of the public interest (Long and Scott 2013). There are 
grounds for skepticism about this critique, principally that capture is most powerful when governance targets have strong, closely aligned material interests at stake. These conditions are not present for solar geoengineering research now, and appear unlikely even under potential future expansion to operational use. Scientific researchers, the targets of governance, are diverse in their views about both the benefits and risks of particular methods, and the promise and risks of the entire approach. No commercial actors are presently active in solar geoengineering, and it appears unlikely that there will be great fortunes at stake even in the event of future deployment. States appear likely to guard their authority over operational decisions, limiting commercial actors to modest procurement roles (Reynolds et al. 2017). Still, capture is a widespread problem in many regulatory areas, both state and nonstate, and cannot be authoritatively dismissed.

Finally, because our analysis assumes current conditions, our conclusions regarding effective nonstate governance may become invalid if these change. Participants in current solar geoengineering debates are conservative, based on a widely shared recognition that badly governed research could trigger a backlash. For example, the SCoPEx group has voluntarily delayed its experiment several years to develop an effective governance system. Funding is a pittance, and most funding programs explicitly identified as solar geoengineering are oriented to governance studies and elaboration of risks and pitfalls. But if concern about the severity and urgency of climate change surges, it is plausible that the issue might attract less cautious actors-perhaps even researchers or funders who are attracted to solar geoengineering's disruptive potential. Such a shift would undermine the effectiveness of the distributed, norm-based, nonstate approach to governance that we propose. While we judge this to be unlikely in the near term, it cannot be confidently ruled out.

\section{Conclusions}

We conclude that suitably configured collaborations among relevant nonstate actorsincluding researchers, their institutions, funders, academic publishers, professional societies, and advocacy NGOs - can effectively and legitimately meet the additional governance needs of near-term solar geoengineering research. This applies to governance of research - not to potential future deployment proposals, nor to future, larger-scale activities with stronger direct impacts, significant transboundary effects, or linkages to other elements of climate response. The critiques of nonstate governance noted above are not compelling under present conditions but could become so with future evolution.

Moreover, although we have assessed nonstate governance as an acceptable alternative given states' lack of engagement, it might actually be preferable at this stage, even if states were involved. As noted, nonstate actors can sometimes draw on superior information about and relations with targets of governance, innovate more, respond more rapidly to changes in knowledge or capacity, engage more readily in contested areas, and operate more flexibly across jurisdictions. For solar geoengineering in particular, early formal state action - even in research governance - may risk prematurely locking in early decisions or unhelpfully entangling the issue with other contentious international debates. With the matter uncertain and rapidly developing, a nonstate system could address immediate concerns, help explore key uncertainties, and delay development of a more legalized regime while some of these early uncertainties are explored and better characterized. 
An initial nonstate approach to research governance may also aid early exploration and development of the more robust and legalized capacities likely to be necessary in the future. As the solar geoengineering and broader climate change issues develop, the high stakes and controversy associated with potential deployment proposals and with linkages to other climate responses will present international social and political challenges that are novel, severe, and presently under-recognized (Parson and Ernst 2013). Some specific functions of near-term research governance - such as assuring transparency, treatment of commercial interests, and assimilating early results to guide evolving strategic planning - will have close parallels in future needs. Even if the particular way these are handled for research is not appropriate for future governance, these early explorations may offer useful insights and help build shared understanding and trust - including across jurisdictions - and so contribute to building necessary future capacity. Moreover, some elements of early nonstate research governance will address these longer-term needs more directly. The concerns about indirect social and political challenges that motivate the program-level consultations we propose are directly relevant to future governance needs. A nonstate approach that supports these consultations will allow early, informal, low-stakes exploration of these issues, with flexible participation that can draw from a wide range of relevant expertise and experience even without involving current government officials. Nonstate governance can thus provide early considerations, guidance, and capacity building toward the more extensive, robust, and legalized governance that will be warranted. In this respect, solar geoengineering could follow the examples of other issues in which early soft-law governance, including mechanisms predominantly or exclusively led by nonstate actors, developed into stronger state-led governance (Karmel and Kelly 2009).

How might a nonstate governance system get started? That the critical element now lacking is financial resources suggests that funders might be best positioned to catalyze the initial steps. Since governance must be built into initial design of a research program, funders - preferably multiple ones - should convene early discussions of program design and governance, involving respected scientists in related fields, research institutions, and professional societies. These could draw relevant insights from the development of a governance system for the first-of-akind SCoPEx project. Program design and governance provisions for individual projects should be developed in parallel with starting consultations on societal impacts and challenges, although these latter processes must involve wider participation, in particular environmental NGOs as well as religious, labor, and other civil society groups. This will be ad hoc and improvised, necessarily relying on cooperative networks of interested institutions and individuals. In view of their experimental character and the value of broad engagement, it would be valuable to have multiple processes operating in parallel, sharing information widely about deliberations and promising outcomes but with no requirement for different groups' approaches to be consistent. As the governance system develops and the solar geoengineering issue evolves, needs will change. New actors may emerge with interests in solar geoengineering. Over time, as the balance of advantage between nonstate and state-led approaches shifts, state participation could gradually increase-via state actor involvement in consultation, increased government research funding alongside nonstate programs, or other means.

\section{Compliance with ethical standards}

Conflict of interest The authors declare that they have no conflict of interest. 
Open Access This article is licensed under a Creative Commons Attribution 4.0 International License, which permits use, sharing, adaptation, distribution and reproduction in any medium or format, as long as you give appropriate credit to the original author(s) and the source, provide a link to the Creative Commons licence, and indicate if changes were made. The images or other third party material in this article are included in the article's Creative Commons licence, unless indicated otherwise in a credit line to the material. If material is not included in the article's Creative Commons licence and your intended use is not permitted by statutory regulation or exceeds the permitted use, you will need to obtain permission directly from the copyright holder. To view a copy of this licence, visit http://creativecommons.org/licenses/by/4.0/.

\section{References}

Abbott KW, Keohane RO, Moravcsik A, Slaughter A-M, Snidal D (2000) The concept of legalization. Int Org 54:401-419

American Association for the Advancement of Science (2018) Revocation process. https://www.aaas. org/programs/fellows/revocation-process. Accessed 17 Oct 2019

American Geophysical Union Council (2009) AGU position statement: geoengineering the climate system: statement adopted by Council 13 December 2009 adopted from the statement written by the American Meteorological Society and adopted by the AMS Council on 20 July 2009. EOS 91:146-147. https://doi. org/10.1029/2010EO160013

American Meteorological Society Council (2013) Geoengineering the climate system: a policy statement of the American Meteorological Society. https://www.ametsoc.org/index.cfm/ams/about-ams/amsstatements/statements-of-the-ams-in-force/geoengineering-the-climate-system/. Accessed 28 Oct 2019

Anshelm J, Hansson A (2014) Battling Promethean dreams and Trojan horses: revealing the critical discourses of geoengineering. Energy Res Soc Sci 2:135-144. https://doi.org/10.1016/j.erss.2014.04.001

Armeni C, Redgwell C (2015) Geoengineering under national law: a case study of the United Kingdom. Climate Geoengineering Governance Working Paper Series 023. http:/www.geoengineering-governance-research. org/perch/resources/workingpaper23armeniredgwelltheukcombine.pdf. Accessed 13 Apr 2020

Asilomar Scientific Organizing Committee (2010) The Asilomar conference recommendations on principles for research into climate engineering techniques. Climate Institute, Washington. http://www.climateresponsefund. org/images/Conference/finalfinalreport.pdf. Accessed 13 Apr 2020

Baldwin R, Cave M, Lodge M (2012) Understanding regulation: theory, strategy, and practice, 2nd edn. Oxford University Press, Oxford. https://doi.org/10.1093/acprof:osobl/9780199576081.001.0001

Bartley T (2011) Certification as a mode of social regulation. In: Levi-Faur D (ed) Handbook on the politics of regulation. Edward Elgar, Cheltenham, pp 441-452. https://doi.org/10.4337/9780857936110.00049

Bernstein S (2011) Legitimacy in intergovernmental and non-state global governance. Rev Int Polit Econ 18:1751. https://doi.org/10.1080/09692290903173087

Betsill MM, Corell E (2008) NGO diplomacy: the influence of nongovernmental organizations in international environmental negotiations. MIT Press, Cambridge

Bill and Melinda Gates Foundation (n.d.-a) Fact sheet. https:/www.gatesfoundation.org/who-we-are/generalinformation/foundation-factsheet. Accessed 8 Oct 2019

Bill and Melinda Gates Foundation (n.d.-b) Sample terms \& conditions, project support grant agreement. https://docs.gatesfoundation.org/documents/sample-terms-and-conditions.pdf. Accessed 28 Oct 2019

Bipartisan Policy Center's Task Force on Climate Remediation Research (2011) Geoengineering: a national strategic plan for research on the potential effectiveness, feasibility, and consequences of climate remediation technologies. Bipartisan Policy Center, Washington. https://bipartisanpolicy.org/wp-content/uploads/2019 /03/BPC-Climate-Remediation-Final-Report.pdf. Accessed 13 Apr 2020

Black J (2001) Decentring regulation: understanding the role of regulation and self regulation in a "postregulatory" world. Curr Legal Prob 54:103-146. https://doi.org/10.1093/clp/54.1.103

Bodansky D (2013) The who, what, and wherefore of geoengineering governance. Clim Chang 121:539-551. https://doi.org/10.1007/s10584-013-0759-7

Boli J, Thomas GM (eds) (1999) Constructing world culture: international nongovernmental organizations since 1875. Stanford University Press, Stanford

Brent K (2018) Solar radiation management geoengineering and strict liability for ultrahazardous activities. In: Craik N, Jefferies CSG, Seck SL, Stephens T (eds) Global environmental change and innovation in international law. Cambridge University Press, Cambridge, pp 161-179. https://doi.org/10.1017 /9781108526081.010 
Burger M, Gundlach J (2018) Research governance. In: Gerrard MB, Hester TD (eds) Climate engineering and the law: regulation and liability for solar radiation management and carbon dioxide removal. Cambridge University Press, Cambridge, pp 269-323. https://doi.org/10.1017/9781316661864.006

Caldeira K (2008) We should plan for the worst-case climate scenario. Bulletin of the Atomic Scientists. https://thebulletin.org/roundtable_entry/we-should-plan-for-the-worst-case-climate-scenario/. Accessed 28 Oct 2019

Chhetri N, Chong D, Conca K et al (2018) Governing solar radiation management. Forum for Climate Engineering Assessment, American University, Washington. http://ceassessment.org/srmreport/. Accessed 13 Apr 2020

Coglianese C, Mendelson E (2010) Meta-regulation and self-regulation. In: Baldwin R, Cave M, Lodge M (eds) The Oxford handbook of regulation. Oxford University Press, Oxford, pp 146-168. https://doi.org/10.1093 /oxfordhb/9780199560219.003.0008

Consortium for Science, Policy \& Outcomes (n.d.) Exploring democratic governance of solar geoengineering research. https:/cspo.org/research/governance-of-geoengineering-research/. Accessed 28 Oct 2019

Dykema JA, Keith DW, Anderson JG, Weisenstein D (2014) Stratospheric controlled perturbation experiment: a small-scale experiment to improve understanding of the risks of solar geoengineering. Phil Trans R Soc A 372:article 20140059. https://doi.org/10.1098/rsta.2014.0059

Editors (2012) Publishing risky research. Nature 485:5. https://doi.org/10.1038/485005a

Edwards GE (2009) Assessing the effectiveness of human rights non-governmental organizations (NGOs) from the birth of the United Nations to the 21 st century: ten attributes of highly successful human rights NGOs. Mich State Univ Coll Law J Int Law 18:165-227. https://digitalcommons.law.msu.edu/ilr/vol18/iss2/5/. Accessed 13 Apr 2020

Ekwurzel B, Boneham J, Dalton MW et al (2017) The rise in global atmospheric $\mathrm{CO}_{2}$, surface temperature, and sea level from emissions traced to major carbon producers. Clim Chang 144:579-590. https://doi. org/10.1007/s10584-017-1978-0

Engineering and Physical Sciences Research Council (2012) SPICE update. https://epsrc.ukri. org/newsevents/news/spiceupdateoct/. Accessed 28 Oct 2019

Environmental Defense Fund (2015) Our position on geoengineering. https://www.edf.org/climate/our-positiongeoengineering. Accessed 28 Oct 2019

Field L, Ivanova D, Bhattacharyya S et al (2018) Increasing arctic sea ice albedo using localized reversible geoengineering. Earth's Future 6:882-901. https://doi.org/10.1029/2018EF000820

Friends of the Earth (2015) Geoengineering: unjust, unproven and risky. https://foe.org/news/2015-02geoengineering-unjust-unproven-and-risky/. Accessed 17 Oct 2019

Frumhoff PC, Stephens JC (2018) Towards legitimacy of the solar geoengineering research enterprise. Phil Trans R Soc A 376:article 20160459. https://doi.org/10.1098/rsta.2016.0459

Garcia Martinez M, Fearne A, Caswell JA, Henson S (2007) Co-regulation as a possible model for food safety governance: opportunities for public-private partnerships. Food Policy 32:299-314. https://doi.org/10.1016 /j.foodpol.2006.07.005

Gardiner SM, Fragnière A (2018) The Tollgate Principles for the governance of geoengineering: moving beyond the Oxford Principles to an ethically more robust approach. Ethics Policy Environ 21:143-174. https://oi. org/10.1080/21550085.2018.1509472

Great Britain Department of Energy and Climate Change (2010) Government response to the house of commons science and technology committee 5th report of session 2009-10: the regulation of geoengineering. The Stationery Office, Norwich. https:/www.gov.uk/government/publications/regulation-of-geoengineeringgovernment-response-to-science-and-technology-committee. Accessed 13 Apr 2020

Gunningham N, Grabosky PN (1998) Smart regulation: designing environmental policy. Oxford University Press, Oxford

Gupta A, Möller I (2018) De facto governance: how authoritative assessments construct climate engineering as an object of governance. Environ Polit 28:480-501. https://doi.org/10.1080/09644016.2018.1452373

Hale B (2012) The world that would have been: moral hazard arguments against geoengineering. In: Preston CJ (ed) Engineering the climate: the ethics of solar radiation management. Rowman and Littlefield, Lanham, pp 113-132

Heyvaert V (2018) Transnational environmental regulation and governance: purpose, strategies and principles. Cambridge University Press, Cambridge. https://doi.org/10.1017/9781108235099

Hubert A-M (2017) Code of conduct for responsible geoengineering research. https://www.ucalgary. ca/grgproject/files/grgproject/revised-code-of-conduct-for-geoengineering-research-2017-hubert.pdf. Accessed 28 Oct 2019

Hulme M (2014) Can science fix climate change? A Case Against Climate Engineering. Polity, Cambridge

Institution of Mechanical Engineers (2009) Geo-engineering: giving us the time to act? https://www.imeche. org/policy-and-press/reports/detail/geo-engineering-giving-us-the-time-to-act. Accessed 13 Apr 2020 
International Commission on Clouds and Precipitation (2014) Statement on radiation management climate engineering. http://www.iccp-iamas.org/pdf/ICCP_RadiationManagement_Statement.pdf. Accessed 28 Oct 2019

IPCC (2018) Global warming of $1.5^{\circ} \mathrm{C}$. IPCC. https://www.ipcc.ch/sr15/. Accessed 13 Apr 2020

Izrael Y, Zakharov V, Petrov N et al (2009) Field studies of a geo-engineering method of maintaining a modern climate with aerosol particles. Russ Meteorol Hydrol 34:635-638. https://doi.org/10.3103 /s106837390910001x

Jamieson D (1996) Ethics and intentional climate change. Clim Chang 33:323-336. https://doi.org/10.1007 /bf00142580

Journal Editors and Authors' Group (2003) Statement on scientific publication and security. Science 299:11491149. https://doi.org/10.1126/science.299.5610.1149

Karmel RS, Kelly CR (2009) The hardening of soft law in securities regulation. Brook J Int Law 34:883-951. https://brooklynworks.brooklaw.edu/bjil/vol34/iss3/10/. Accessed 13 Apr 2020

Keck ME, Sikkink K (2014) Activists beyond borders: advocacy networks in international politics. Cornell University Press, Ithaca

Keith D, Dykema J (2018) Why we chose not to patent solar geoengineering technologies. https://keith.seas. harvard.edu/blog/why-we-chose-not-patent-solar-geoengineering-technologies. Accessed 28 Oct 2019

Keutsch Research Group, Harvard University (n.d.) SCoPEx governance. https://projects.iq.harvard. edu/keutschgroup/scopex-governance. Accessed 28 Oct 2019

Kruger T (2018) A commentary on the Oxford Principles. In: Blackstock JJ, Low S (eds) Geoengineering our climate?: ethics, politics and governance. Routledge, London and New York, pp 190-198

Larivière V, Haustein S, Mongeon P (2015) The oligopoly of academic publishers in the digital era. PLoS One 10:article e0127502. https://doi.org/10.1371/journal.pone.0127502

Lentzos F (2017) Genetic engineering and biological risks: policy formation and regulatory response. In: Brownsword R, Scotford E, Yeung K (eds) The Oxford handbook of law, regulation and technology. Oxford University Press, Oxford, pp 1118-1141. https://doi.org/10.1093/oxfordhb/9780199680832.013.66

Levelt Committee, Drenth Committee, Noort Committee (2012) Flawed science: the fraudulent research practices of social psychologist Diederik Stapel

Long J, Parson EA (2019) Functions of geoengineering research governance. https://papers.ssrn. com/abstract=3476376. Accessed 28 Oct 2019

Long JCS, Scott D (2013) Vested interests and geoengineering research. Issues Sci Technol 29:45-52. https://issues.org/long-4/. Accessed 13 Apr 2020

MacMartin DG, Kravitz B (2019) Mission-driven research for stratospheric aerosol geoengineering. Proc Natl Acad Sci 116:1089-1094. https://doi.org/10.1073/pnas.1811022116

Marchant GE, Wallach W (2015) Coordinating technology governance. Issues Sci Technol 31:43. https://issues. org/coordinating-technology-governance/. Accessed 13 Apr 2020

Marshall M (2012) Independent geoengineer's ocean field test condemned. New Scientist. https://www. newscientist.com/article/dn22390-independent-geoengineers-ocean-field-test-condemned/. Accessed 28 Oct 2019

McDonald J, McGee J, Brent K, Burns W (2019) Governing geoengineering research for the Great Barrier Reef. Clim Pol 19:801-811. https://doi.org/10.1080/14693062.2019.1592742

Morrow DR, Kopp RE, Oppenheimer M (2009) Toward ethical norms and institutions for climate engineering research. Environ Res Lett 4:article 045106. https://doi.org/10.1088/1748-9326/4/4/045106

National Academy of Sciences (2018) Code of conduct. http://www.nasonline.org/about-nas/code-ofconduct/nas-code-of-conduct.pdf. Accessed 28 Oct 2019

National Research Councils (2015) Climate intervention: reflecting sunlight to cool earth. National Academies Press, Washington

Natural Resources Defense Council (2015) Geoengineering: research is prudent, but no substitute for carbon pollution cuts. https://www.nrdc.org/media/2015/150210. Accessed 28 Oct 2019

Nature (2018) Announcement: stem-cell policy. Nature 557:6. https://doi.org/10.1038/d41586-018-05030-2

Necheles E, Burns L, Chang A, Keith D (2018) Funding for solar geoengineering from 2008 to 2018. https://geoengineering.environment.harvard.edu/blog/funding-solar-geoengineering. Accessed 28 Oct 2019

Nicholson S, Jinnah S, Gillespie A (2018) Solar radiation management: a proposal for immediate polycentric governance. Clim Pol 18:322-334. https://doi.org/10.1080/14693062.2017.1400944

Parker A (2014) Governing solar geoengineering research as it leaves the laboratory. Phil Trans R Soc A 372: article 20140173. https://doi.org/10.1098/rsta.2014.0173

Parson EA, Ernst LN (2013) International governance of climate engineering. Theor Inq Law 14:307-337. https://oi.org/10.1515/til-2013-015

Parson EA, Keith DW (2013) End the deadlock on governance of geoengineering research. Science 339:12781279. https://doi.org/10.1126/science. 1232527 
Rayner S, Heyward C, Kruger T et al (2013) The Oxford Principles. Clim Chang 121:499-512. https://doi. org/10.1007/s10584-012-0675-2

Rees J (1994) Hostages of each other: the transformation of nuclear safety since Three Mile Island. University of Chicago Press, Chicago

Reynolds J (2014) The international regulation of climate engineering: lessons from nuclear power. J Environ Law 26:269-289. https://doi.org/10.1093/jel/equ006

Reynolds JL (2019) The governance of solar geoengineering: managing climate change in the Anthropocene. Cambridge University Press, Cambridge. https://doi.org/10.1017/9781316676790

Reynolds JL, Contreras JL, Sarnoff JD (2017) Solar climate engineering and intellectual property: toward a research commons. Minn J Law Sci Technol 18:1-110. https:/scholarship.law.umn.edu/mjlst/vol18/iss1/1/. Accessed 13 Apr 2020

Russell LM, Sorooshian A, Seinfeld JH et al (2013) Eastern Pacific emitted aerosol cloud experiment. Bull AMS 94:709-729. https://doi.org/10.1175/BAMS-D-12-00015.1

Sargoni J (2016) The best of both worlds: maximising the legitimacy of the EU's regulation of geoengineering research. Eur J Risk Regul 7:87-108. https://doi.org/10.1017/S1867299X00005420

Schäfer S, Lawrence M, Stelzer H et al (2015) The European transdisciplinary assessment of climate engineering (EUTRACE): removing greenhouse gases from the atmosphere and reflecting sunlight away from earth. https://www.iass-potsdam.de/sites/default/files/files/rz_150715_eutrace_digital_0.pdf. Accessed 13 Apr 2020

Schellnhuber HJ (2011) Geoengineering: the good, the MAD, and the sensible. Proc Natl Acad Sci 108:2027720278. https://doi.org/10.1073/pnas.1115966108

Science News Staff (2018) Trump, Congress approve largest U.S. research spending increase in a decade. Science. https://www.sciencemag.org/news/2018/03/updated-us-spending-deal-contains-largest-researchspending-increase-decade. Accessed 8 Oct 2019

Shepherd J, Caldeira K, Haigh J et al (2009) Geoengineering the climate: science, governance and uncertainty. The Royal Society, London. https://royalsociety.org/ /media/Royal_Society_Content/policy/publications/2009 18693.pdf. Accessed 13 Apr 2020

Solar Radiation Management Governance Initiative (2011) Solar radiation management: the governance of research. Solar Radiation Management Governance Initiative. http://www.srmgi.org/files/2016/02/SRMGI. pdf. Accessed 13 Apr 2020

SPICE (n.d.) What is geoengineering? http://www.spice.ac.uk/about-us/geoengineering/. Accessed 28 Oct 2019

Stilgoe J, Watson M, Kuo K (2013) Public engagement with biotechnologies offers lessons for the governance of geoengineering research and beyond. PLOS Biol 11:article e1001707. https://doi.org/10.1371/journal. pbio. 1001707

UK House of Commons Science and Technology Committee (2010) The regulation of geoengineering. The Stationery Office, London. https://publications.parliament.uk/pa/cm200910/cmselect/cmsctech/221/22102. htm. Accessed 13 Apr 2020

Union of Concerned Scientists (2019) UCS position on solar geoengineering. https:/www.ucsusa. org/sites/default/files/attach/2019/gw-position-Solar-Geoengineering-022019.pdf. Accessed 28 Oct 2019

Winter SC, May PJ (2001) Motivation for compliance with environmental regulations. J Policy Anal Manag 20: 675-698. https://doi.org/10.1002/pam.1023

Wood R, Ackerman TP (2013) Defining success and limits of field experiments to test geoengineering by marine cloud brightening. Clim Chang 121:459-472. https://doi.org/10.1007/s10584-013-0932-z

World Medical Association (2018) WMA Declaration of Helsinki: ethical principles for medical research involving human subjects. https:/www.wma.net/policies-post/wma-declaration-of-helsinki-ethicalprinciples-for-medical-research-involving-human-subjects/. Accessed 28 Oct 2019

Zelli F, Möller I, van Asselt H (2017) Institutional complexity and private authority in global climate governance: the cases of climate engineering, REDD+ and short-lived climate pollutants. Environ Polit 26:669-693. https://doi.org/10.1080/09644016.2017.1319020

Publisher's note Springer Nature remains neutral with regard to jurisdictional claims in published maps and institutional affiliations. 